\title{
Review
}

\section{The form of politics: Aristotle and Plato on friendship}

\author{
John Von Heyking (ed.) \\ McGill-Queen's University Press, 2016, xv + 227 pp., \\ ISBN: 978-0-7735-4756-8
}

Contemporary Political Theory (2018) 17, S236-S239. https://doi.org/10.1057/s41296017-0148-5; published online 19 September 2017

Contemporary scholars have taken up the gauntlet thrown down at them by C. $\mathrm{S}$. Lewis who famously admonished that while ' $[\mathrm{t}] \mathrm{o}$ the Ancients, Friendship seemed the happiest and most fully human of all loves; the crown of life and the school of virtue. The modern world, in comparison, ignores it' (1960, p. 87). Indeed, Lewis would hopefully look favourable upon contemporary attempts to make sense of friendship, whether in history (Caine, 2014), in Politics (Smith, 2011), in International Relations (Koschut and Oelsner, 2014), or in Foreign Policy Analysis (Berenskoetter and Van Hoef, 2017). While these works debate the essence of friendship, other works focus on the narratives of friendships between political actors (Reid-Henry, 2009; Meacham, 2003). In the media as well, friendships between politicians can count upon heightened scrutiny, best illustrated by the attention newspapers give to the joint walks on the beach of French Presidents and German Chancellors. Indeed, Chancellor Angela Merkel and former French President Nicolas Sarkozy even earned the moniker Merkozy in the press (Van Hoef, 2014, p. 63). Ancient works on friendships can count upon renewed interest as well, and it is here where John Von Heyking's work, based upon an elaborate reading of Plato and Aristotle, can be placed.

Because of the renewed interest in friendship, the first critical question must be whether Von Heyking has anything to add to previous interpretations (such as: Smith Pangle, 2008; Vlastos, 2000). Because friendship pervaded both Greek personal and political culture, it is no wonder that the Greeks made friendship the centre of their political theory. Despite Plato's prominence, most works focusing on friendship draw upon Aristotle's three conceptualizations of friendship, rather than those of Plato. Friendship is addressed in several of Plato's works, most prominently in his Symposium, Lysis, and also in his Phaedrus. Plato's account of friendship has been criticized for being cold-hearted and egocentric, most prominently by Gregory Vlastos who concluded that Plato was not interested in other individuals for their own sake, but for his own needs and desires (a spiritual

(C) 2017 Macmillan Publishers Ltd. 1470-8914 Contemporary Political Theory Vol. 17, S4, S236-S239 
growth towards the Forms) (Vlastos, 2000). Like Frisbee C. C. Sheffield, Von Heyking draws upon Plato to provide a complete picture of political friendship, which is possible because Plato, in contrast to Aristotle, does not offer an account where friendship focuses solely on the other as an individual (Sheffield, 2011, p. 251).

Von Heyking's work serves as a great introduction to Aristotle and Plato's views on friendship, further cementing their seminal demarcations as the foundations upon which our conceptualizations of friendship must rest. To new students of friendship, The form of politics is a great introductory work to Plato and Aristotle, aided considerably by the fact that Von Heyking does not assume any prior knowledge of the reader, and therefore also consistently offers both the original Greek and the English translations of important concepts side by side. Students are either introduced or reacquainted with terms such as virtue-friendship (sunaisthesis: the joint perception of the good), utility, and pleasure-friendship. To the contemporary debate on friendship, Von Heyking offers a very important reconceptualization by bringing our attention to an oft-overlooked aspect of the ancient concept of political friendship: that of festivity. Von Heyking does this by strongly differentiating virtue-friendship from political friendship; the friendship of the city, of the community, and showing how the ideal Polis debated by the Athenian Stranger in Plato's Laws must culminate in the shared experience of festivity.

The heart of the work, and its most praiseworthy ambition, lies in not only drawing our attention to the role of festivity, but also in trying to acquaint us with something that is so very far removed from our contemporary understanding, because: "[m]odern life offers few opportunities for such experiences of 'withness' in song and dance. We veer between the crowd-forming (rather than societyforming) ecstasies of popular music, and the rationalist contempt of Jane Austen's Mr. Darcy, who refuses to join Elizabeth Bennett and her circle in dancing" (pp. 166-167). It is here that I have a minor gripe with the work. For although a number of illustrative examples of festivity are mentioned, such as Alexandr Onishenko's impressionistic painting "Jewish Dance" and the Maori haka dance (p. 166), the book does not contain illustrations of these experiences that come close to festivity. The beautiful, but very safe cover, offers the familiar School of Athens with Plato and Aristotle singled out. While an image would never convey the entirety and complexity of what a city or a political community engaging in festivity would entail, an illustration that comes partway is sorely lacking. This is noticeable too in the final chapter where the Calgary Stampede is dealt with in-depth as an illustration of a political community engaging in festivity. One or two striking images of festivity would have further strengthened the author's insight.

To an extent, the same goes for Von Heyking's easy dismissal of Robin Dunbar in comparison with Aristotle because the latter, "does not derive an algorithm to determine the optimal number of friends" (p. 84). It seems to me that some of the

(c) 2017 Macmillan Publishers Ltd. 1470-8914 Contemporary Political Theory $\quad$ Vol. 17, S4, S236-S239 S237 
insights of Dunbar's extensive and ongoing quantitative analysis of friendship would complement, indeed even strengthen some of Von Heyking's findings. For instance, Dunbar's research posits that humans bond through gossip: is there not some overlap with Von Heyking's citizen's that share in festivity? (Sutcliffe et al., 2012, p. 155). Does Dunbar's number (of average friends that a human can have) hold any further significance? It might, because this size of around 150:

has been documented in a wide range of social, cultural, and historical circumstances, representing both top-down (community level) and bottom-up (egocentric personal network) perspectives [...] Examples include community size in traditional hunter-gatherers, average countywide village sizes in both the Domesday Book and eighteenth century England, company size in historical and modern armies, and parish sizes among the Amish and Huterites (Sutcliffe et al., 2012, p. 151).

It might very well be that the average of a 150 close personal relationships does not only limit human relationships, but also restricts the amount of people that can participate in festivity, which then has important ramifications for this newly discovered concept. Von Heyking's festivity begs to be further developed in debate with some of these other fundamental findings in the study of friendship.

In sum, Von Heyking offers scholars a great introduction to Plato and Aristotle's insights on political friendship, aptly differentiating between virtue-friendship on the one hand, and political friendship on the other. The most intriguing aspect of Von Heyking's work is the idea of how the political community comes together and strengthens itself through festivity, an overlooked aspect of political friendship the author brilliantly brings back to the fore. The work is filled with both historical and contemporary examples of both forms of friendship, further adding to the book's value as a reference work. If there is a weakness to be found, it is that some friendship scholars and their relevant insights should have been further called upon which, would have strengthened Von Heyking's findings. That being said, there is no doubt that C. S. Lewis too would look favourable upon The Form of Politics, and perhaps it even would have convinced him to add festivity as the Fifth Love.

\section{References}

Berenskoetter, F. and Van Hoef, Y. (2017) Friendship and foreign policy, July. doi:10.1093/acrefore/ 9780190228637.013.429.

Caine, B. (ed.) (2014) Friendship: A History. London: Routledge.

Koschut, S. and Oelsner, A. (eds.) (2014) Friendship and International Relations. Basingstoke: Palgrave Macmillan.

Lewis, C.S. (1960) The Four Loves. New York: Harcourt, Brace.

Meacham, J. (2003) Franklin and Winston: An Intimate Portrait of an Epic Friendship, 1st edn. New York: Random House. 
Reid-Henry, S. (2009) Fidel and Che: A Revolutionary Friendship, 1st U.S. edn. New York: Walker and Co.

Sheffield, F.C.C. (2011) VIII-Beyond eros: Friendship in the Phaedrus. Proceedings of the Aristotelian Society 111(2): 251-273. doi:10.1111/j.1467-9264.2011.00308.x.

Smith, G.M. (2011) Friendship and the Political: Kierkegaard, Nietzsche, Schmitt. Exeter: Imprint Academic.

Smith Pangle, L. (2008) Aristotle and the Philosophy of Friendship. Paperback re-issue, digitally printed version. Cambridge: Cambridge University Press.

Sutcliffe, A., Dunbar, R., Binder, J. and Arrow, H. (2012) Relationships and the social brain: Integrating psychological and evolutionary perspectives. British Journal of Psychology 103(2): 149-168. doi:10. 1111/j.2044-8295.2011.02061.x.

Van Hoef, Y. (2014) Friendship in world politics: Assessing the personal relationships between Kohl and Mitterrand, and Bush and Gorbachev. AMITY: The Journal of Friendship Studies 2(1): 62-82.

Vlastos, G. (2000) The individual as an object of love in Plato. In: G. Fine (ed.) Plato 2. Ethics, Politics, Religion, and the Soul. Oxford Readings in Philosophy. Oxford: Oxford University Press, pp. 137-164.

Yuri van Hoef

Utrecht University, 3512 BS Utrecht, Netherlands y.vanhoef@uu.nl 